\title{
Globalization and Foreign Trade: Selected Topics in Central European Countries
}

\author{
Jaroslav Kovárník ${ }^{1, *}$, Eva Hamplová1 \\ ${ }^{1}$ University of Hradec Králové, Faculty of Informatics and Management, Department of Economics, \\ Rokitanského 62, 500 03, Hradec Králové, Czech Republic
}

\begin{abstract}
Foreign trade plays important role in the economy of every country, especially in modern globalized world. This article deals with selected aspects of foreign trade in countries from central Europe, namely in the Czech Republic, Slovakia, Poland, Hungary, Germany, and Austria. Method of comparative analysis has been used in this article. Firstly, the article analyses the development of GDP (foreign trade is part of GDP formula in every open economy), where the most powerful economies are Germany and Austria. Secondly, overall development of trade with goods and services in all selected countries has been analysed. Surprisingly, the only country with deficit in case of services is Germany. Thirdly, the article focuses on development in two countries, namely of the Czech Republic and Slovakia. The openness of these two countries is compared, but most of all, the export and import of these two countries in relation with other analysed countries. Relatively surprising result is that for both countries is the most important business partner Germany, but there are some differences. Detail results are described in the article.
\end{abstract}

\section{Introduction}

Foreign trade is very important for every state all around the world because it is, among others, part of macroeconomic Gross Domestic Product (GDP) formula. In other words, it can either improve the GDP level (in case that export is higher than import) or worsen it. This basic theory has been explained in many books and articles, for example in [1, 2]. Nevertheless, foreign trade is important for every country because of other reasons as well. In almost all countries worldwide, foreign trade helps solving the proportionality problem, where only few countries have all necessary resources in quantities required for economic development. From above mentioned text is clear that foreign trade is very important for every country. The importance of foreign trade has been evaluated in other articles by other authors, for example $[3,4,5,6,7,8,9,10]$. Authors themselves already analysed the topic of foreign trade several times, for example in $[11,12]$.

The Czech Republic is a member state of Visegrad Four, and all other member states (namely Poland, Slovakia, and Hungary) are very important business partners for the Czech Republic. Situation in Visegrad Four countries has been also analysed by other authors, for example by [13]. However, there are other important economies in the central Europe,

\footnotetext{
* Corresponding author: jaroslav.kovarnik@uhk.cz
} 
namely Germany and Austria, where these two countries are not only strong and powerful economies, but also important business partners for whole V4.

The aim of this article is to analyse the selected aspects of foreign trade in above mentioned countries, namely in the Czech Republic, Poland, Hungary, Slovakia, Austria, and Germany. Firstly, this article analyses the development of GDP in selected countries, because of the importance of foreign trade for this indicator. Secondly, the article analyses the overall development of trade with goods and services. Last analysed topic is deep analysis of trade in two selected countries, namely in the Czech Republic and Slovakia, because of the common history of these two countries. This deep analysis is firstly about the openness of these two countries, and secondly about export and import with respect to other analysed countries.

\section{Methodology and Data}

Covered period of time is 2000 - 2018, where data were obtained in general available database Eurostat and calculated by authors [14, 15]. Methods of comparison and comparative analysis have been used in this article. Moreover, several different calculations can be used for the verification of above mentioned hypothesis about openness of economy. One of the most frequently used calculations measures the relation between export and GDP, where more open economies usually have high ratio. There are other possible indicators how can be openness evaluated, but with respect to the length of this article has been used only export on GDP ratio.

It is also important to add that the calculations are made per capita. It is quite obvious that the position of Germany is completely different compared to the other countries in absolute amounts. The reason is that Germany is not only powerful economy, but it has also the highest number of inhabitants (Germany has more than 82.7 billion in 2018, where Poland has almost 38 billion, the Czech Republic around 10.6 billion, Hungary around 9.8 billion, Austria almost 9 billion, and Slovakia around 5.5 billion). Therefore it is almost impossible to compare absolute amounts in these six countries, and all calculations have been made per capita.

\section{Results}

\subsection{GDP Development Analysis}

Because of the highest number of inhabitants in Germany is quite obvious that the level of GDP in billions of euro is the highest in Germany, and second highest in Poland, where these two countries have significantly more number of inhabitants than the others. However, on the third position is Austria, next is the Czech Republic, after that Hungary, and Slovakia is on the last position.

As was already explained, it is better to use the level of GDP per capita for comparison. According to this, the highest level is in Austria, Germany is on the second position, the Czech Republic is on the third place, Slovakia is the fourth, next is Hungary, and Poland is the last. With respect to this information is good to add one interesting fact. Even if the development in the number of inhabitants in each country has not been steady, this number grew in Austria, in Germany, in the Czech Republic and in Slovakia (comparison of the years 2000 and 2018), while it dropped in Hungary and Poland.

Deep analysis of GDP development shows that in all analysed countries was significant decrease in this indicator in the year 2009 (both in absolute value and in per capita) as a result of global economic crisis. However, the after crisis development is different. All countries were growing since 2009, but only Austria, Germany, and Slovakia managed to exceed pre-crisis year 2008 already in 2010, where other countries achieved higher value 
later (2011 in case of the Czech Republic and Poland, and 2015 in Hungary). Moreover, the after-crisis development is different. Austria, Germany, and Slovakia have been growing since 2009 for the whole analysed period, where the Czech Republic was decreasing between 2012 and 2014, and it has been growing again since 2015. Hungary has been increasing since the 2009 with the only exception in 2012, and Poland has been also increasing for the whole after-crisis period with the only exception in 2016.

It is quite interesting that Slovakia is the only V4 member with similar development in terms of GDP per capita as advanced economies Germany and Austria. On the other hand, its level of GDP per capita is significantly weaker. However, its position is getting better. Slovakia was on the last position in 2000, and it is already better than Hungary and Poland.

Following Fig. 1 describes the development of GDP per capita in all analysed countries.

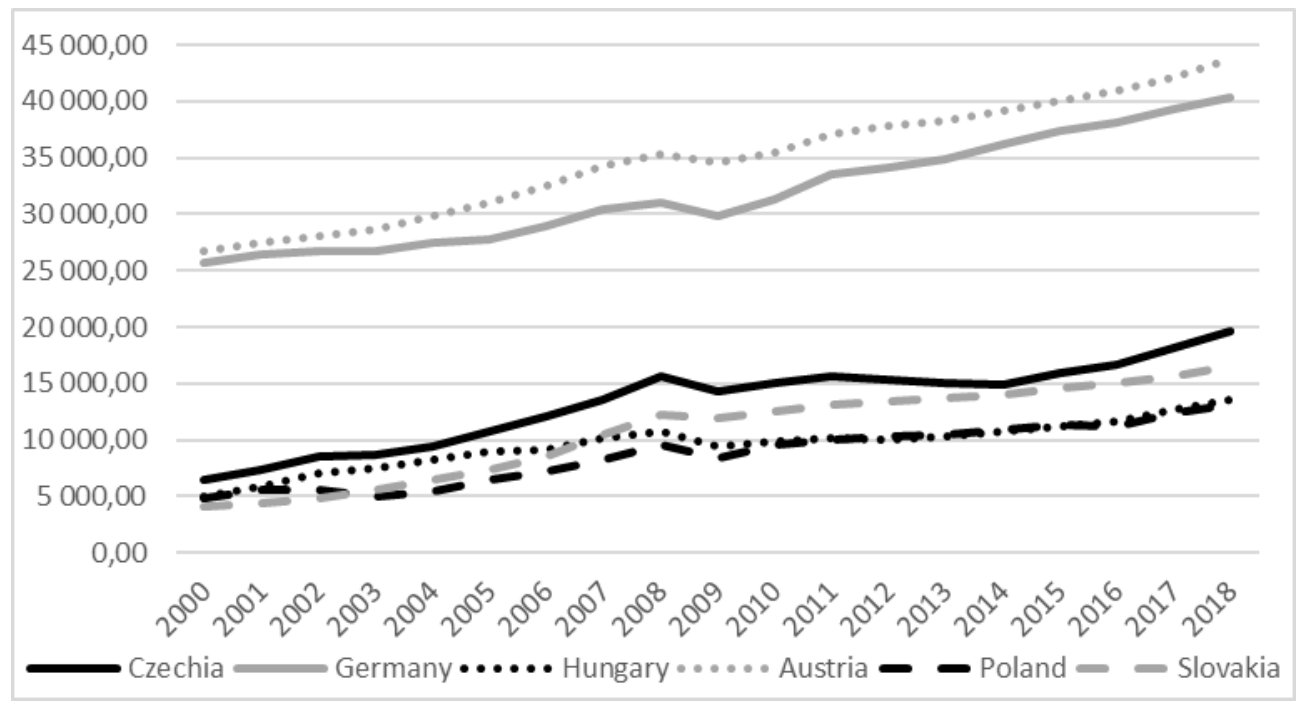

Fig. 1. GDP per Capita Development (own processing based on $[14,15]$ )

\subsection{Trade with Goods}

In terms of GDP per capita are Germany and Austria significantly stronger than all V4 countries. However, the analysis of trade with goods only brings relatively surprising results. In 2000, the only country with surplus was Germany, and the highest deficit was in the Czech Republic (the order of countries was Germany, Slovakia, Poland, Austria, Hungary, and the Czech Republic).

In 2018, the highest surplus was still in Germany, but on the second position was already the Czech republic with surplus more than 800 euro per capita, Austria was the third (with surplus only little bit more than 300), on fourth position was Slovakia, and Poland with Hungary are the only countries with deficit per capita. The development of trade with goods only is described in following Fig. 2. 


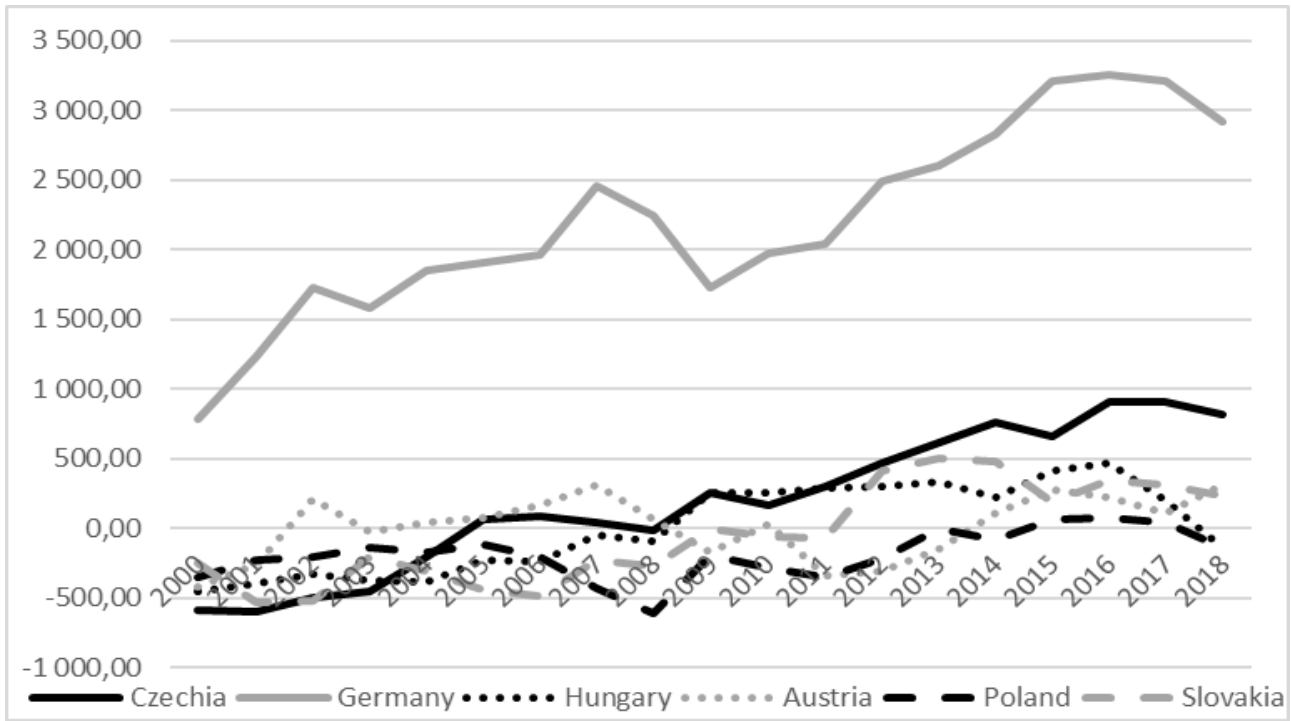

Fig. 2. Trade with Goods per Capita Development (own processing based on [14, 15])

It is quite obvious that the development of balance with goods is quite irregular, especially in comparison with GDP development. However, relatively interesting fact is that in 2009, when GDP per capita decreased in all analysed countries, trade with goods per capita decreased only in Austria and Germany (economically strong and powerful countries), where it grew in all V4 countries. On the other hand, the balance grew in Austria and Germany in 2010, and decreased in all V4 countries. That means that Slovakia, even if it has similar development as advanced economies in terms of GDP, it has similar development as other V4 countries in terms of trade with goods.

\subsection{Trade with Services}

If we analyse trade with services only, we got very surprising results. The only country with the deficit for the whole analysed period is Germany. All other countries had surpluses, with the only exception of Slovakia between 2008 and 2011, but this deficit was still lower than in case of Germany.

The highest surplus in case of trade with services in 2000 was in Austria, the Czech Republic was on the second place, next was Hungary, Slovakia, Poland, and Germany was the last. However, the order in 2018 is again relatively surprising. On the first position is still Austria, but on the second position (per capita) is already Hungary, Poland is on the third position, the Czech Republic is next, and on the fifth position is Slovakia. That means that the weakest countries from V4 (Poland and Hungary) in terms both of GDP per capita and trade with goods per capita are surprisingly growing in terms of trade with services. On the other hand, strong and powerful Germany is obviously focusing only on trade with goods, where its position is almost incomparable with other analysed countries.

The development is again quite irregular, with lot of increases and decreases in all analysed countries. However, some interesting fact are obvious also from comparison of balances in 2000 and 2018. This balance was lower in 2000 in case of Germany, Hungary, Poland, and Austria, but it is lower in 2018 in case of Slovakia and the Czech Republic. That means that both countries of former Czechoslovakia are, despite several increases and decreases, on almost same level in terms of trade with services per capita, where all other analysed countries grew. This growth can be seen especially in case of Hungary and Poland. 
The development of trade with services only is described in the following Fig. 3.

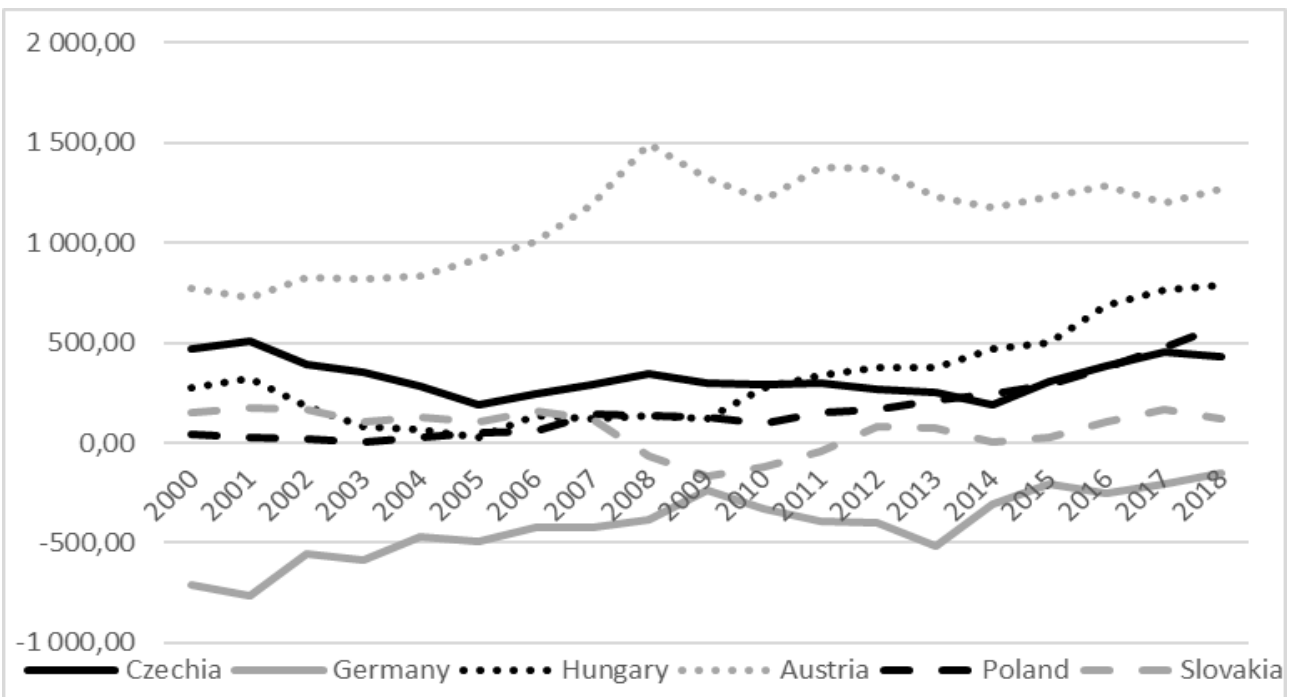

Fig. 3. Trade with Services per Capita Development (own processing based on [14, 15])

\subsection{Openness of the Selected Countries}

The openness of the country measures, in a way, the dependency of the country on foreign trade. Countries that are more open are usually more dependent on foreign trade. Moreover, according to the theory, large (in terms of population and area) and economically powerful economies are usually less dependent.

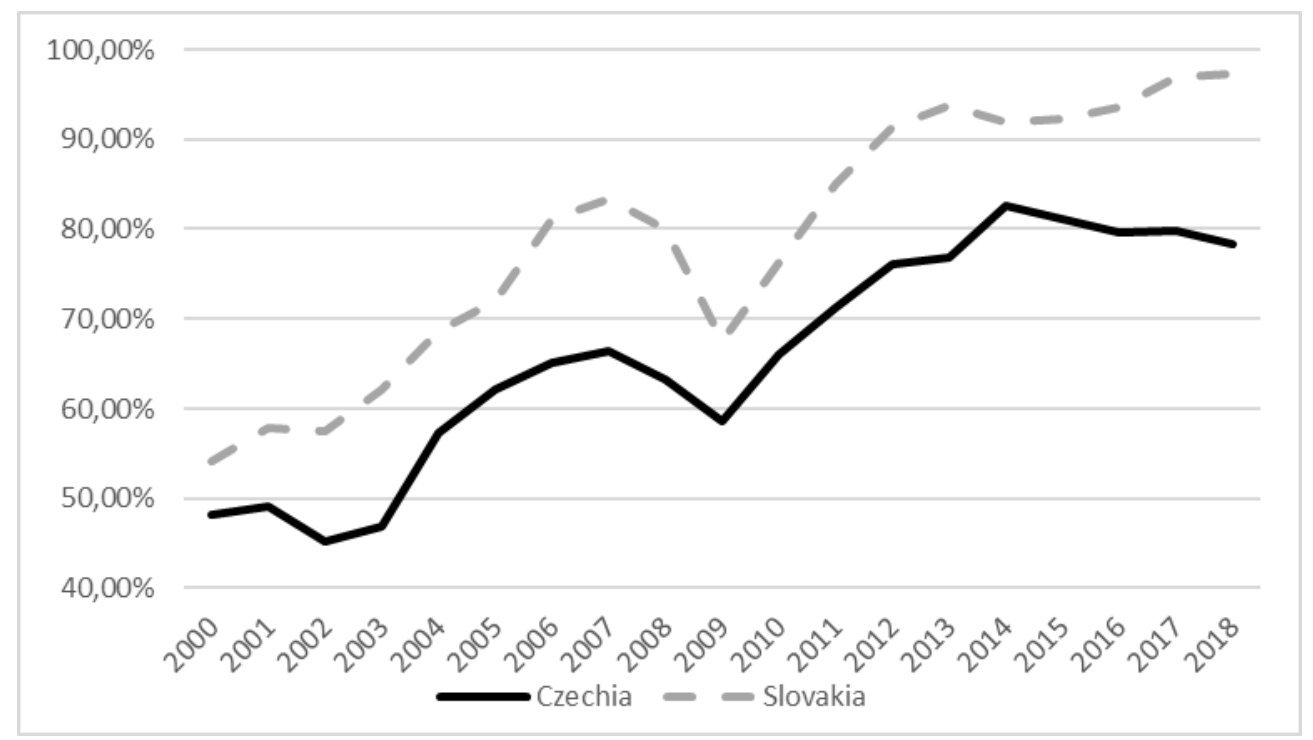

Fig. 4. Openness of Selected Countries (own processing based on [14, 15])

Openness of the economy can be evaluated by lots of different indicators, for example export on GDP ratio, import on GDP ratio, turnover of foreign trade on GDP ratio, etc. However, the results of these indicators are usually similar. Because of the limited space of this article has been calculated only export on GDP ratio for two selected countries, namely 
for the Czech Republic and Slovakia. These countries have been selected because of the common history and because of the place of origin of the authors.

Above presented Fig. 4 supports theoretical proclamation about the openness of the economy. Even if both countries are relatively dependent on foreign trade (in 2018, the share is almost $80 \%$ in case of the Czech Republic, and more than $97 \%$ in case of Slovakia), the Czech Republic is not only larger country with almost twice more inhabitants, but it is also economically more powerful country. Therefore, this country is less open than Slovakia. The analysis also shows relatively high volatility of this indicator, compared to GDP per capita. That means that export and import of both countries change more than GDP in these countries. It can be also seen that in Slovakia, the openness has been growing since 2014, where in case of the Czech Republic has been this indicator decreasing.

\subsection{Foreign Trade in the Czech Republic and Slovakia}

The cooperation with other analysed countries is described in this chapter. Following Fig. 5 describes the balance of the Czech Republic in foreign trade with goods, where following Fig. 6 describes the balance of Slovakia.

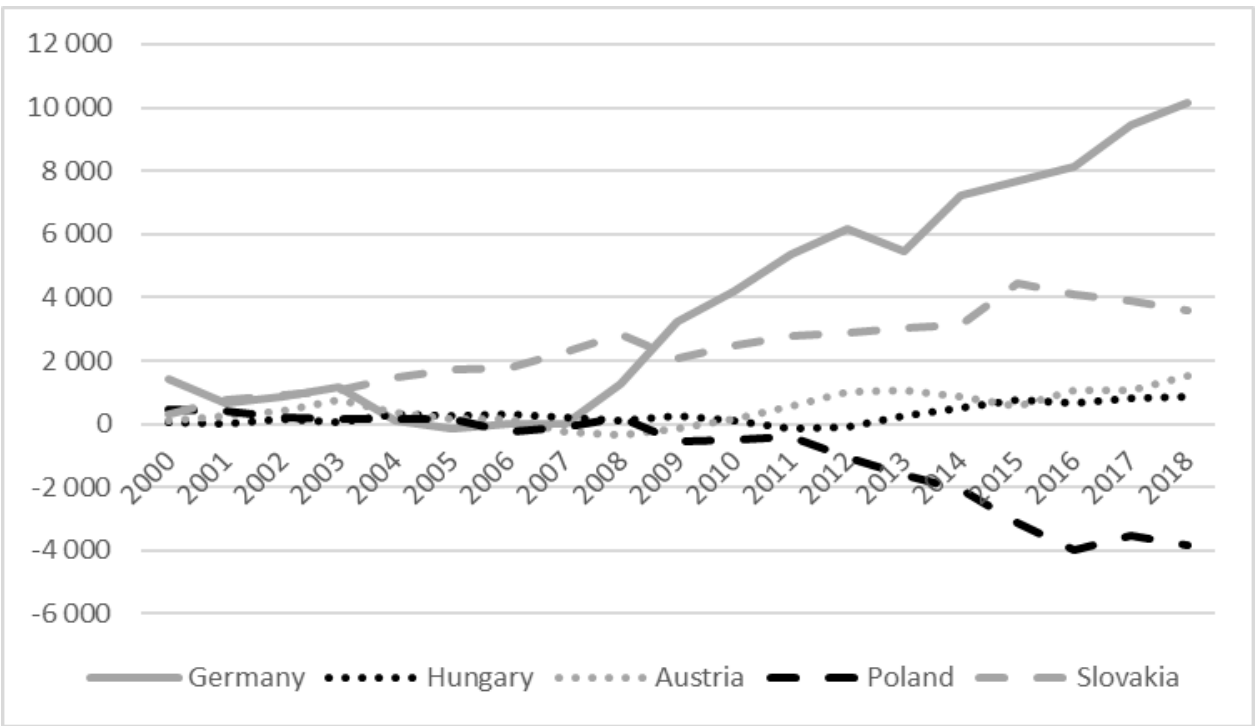

Fig. 5. Balance of the Czech Republic with other Countries (own processing based on $[14,15]$, mill. euro)

Fig. 5 shows that the most important business partner of the Czech Republic is Germany. However, this importance started after economic crisis, where before crisis was the most important partner Slovakia. Nevertheless, the position of Germany has been growing since economic crisis, which means that the export of the Czech Republic in this economy has been growing significantly, compared not only with the import from Germany, but also with the trade with all other countries. Moreover, it is also obvious that the position of Poland has been decreasing since 2012. That means, on the other hand, that the import from Poland in the Czech Republic has been growing since this year. The position of Austria and Hungary is almost the same for the whole analysed period, position of Slovakia improved a little bit (comparison of 2000 and 2018), but the balance has been decreasing since 2015 . 


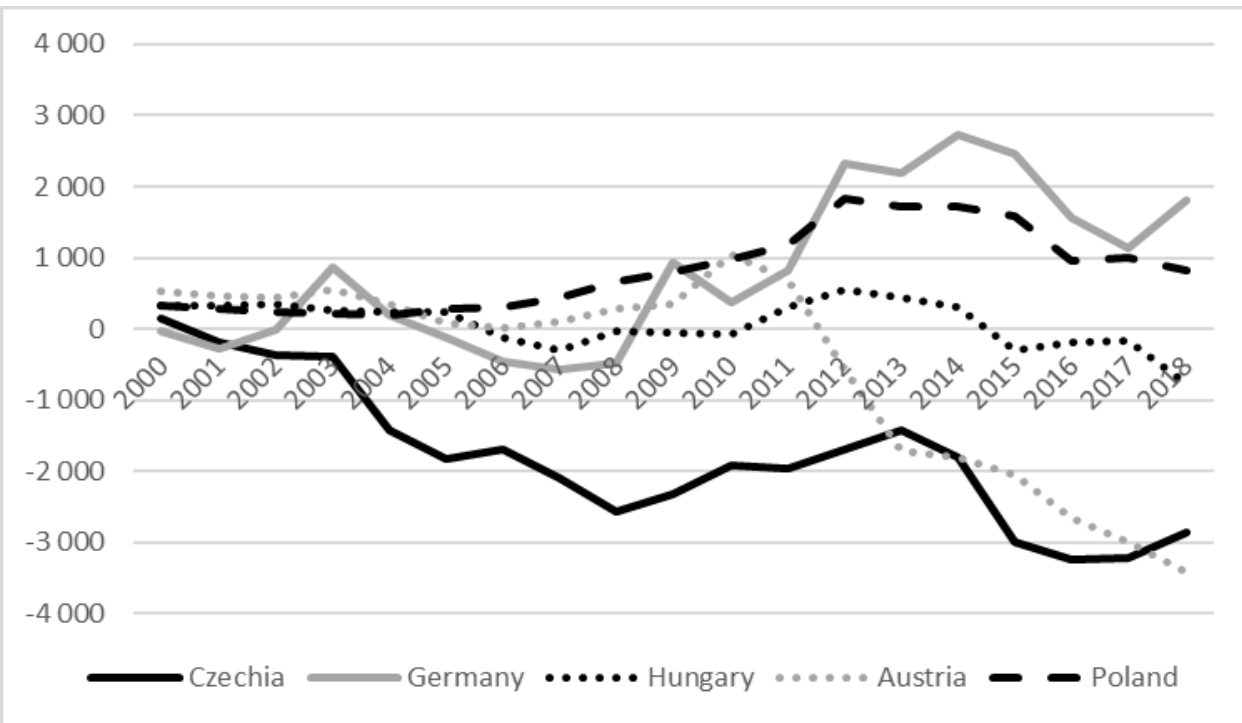

Fig. 6. Balance of Slovakia with other Countries (own processing based on [14, 15], mill. euro)

It is obvious that the balance of Slovakia with other countries is more volatile than in case of the Czech Republic. Surprisingly, the most important partner for Slovakia's export is also Germany, because this country is on the first place. On the second position is Poland, where in case of the Czech Republic is the balance in serious deficit (Slovakia is importing from the Czech Republic more than exporting in this country). Interesting development has been in case of Austria. The balance was in small surplus until 2010, but it has been strongly decreasing since 2011. It can be a consequence of introduction of euro in Slovakia in 2009. It is possible that because of the same currency grew import from Austria significantly.

\section{Conclusions}

The aim of this article was to analyse the selected aspects of foreign trade in countries from the Central Europe, namely in the Czech Republic, Poland, Hungary, Slovakia, Austria, and Germany. The most powerful economies in terms of GDP are Germany and Austria, where all V4 countries can be considered as developing countries. However, GDP in Slovakia has similar development as in two advanced economies. Nevertheless, this similarity is not obvious in case of trade with goods, where the most powerful economy is Germany, but both Germany and Austria are again developing similarly, where Slovakia is already developing similar to other V4 countries.

Surprising result can be seen in case of trade with services only, where the weakest economy for the whole analysed period of time is Germany. On the other hand, relatively strong countries in case of services are Poland and Hungary.

The openness was analysed in case of the Czech Republic and Slovakia, where has been confirmed the theoretical assumption. Slovakia is smaller and economically weaker country, and it is also more open than the Czech Republic.

As far as the trade with other analysed countries is concerned, for both countries is the most important partner for export Germany. Nevertheless, the trade with other countries is relatively different. The Czech Republic is exporting to Slovakia and importing especially from Poland, where Slovakia is exporting into Poland and importing especially from Austria. 
This study is supported by internal research project "Investment within concept Industry 4.0" at Faculty of Informatics and Management, University of Hradec Kralove, Czech Republic. It was prepared in cooperation with student of Ph.D. study at Department of Economics, namely with Ing. Martin Král.

\section{References}

1. A. B. Andrews, B. Bernake, D. D. Croushore, Macroeconomics, (Addison-Wesley, Boston, 2011).

2. P. A. Samuelson, W. D. Nordhaus, Economics, (McGraw-Hill/Irwin, Boston, 2010).

3. S. L. Baier, J. H. Bergrstrand, M. Feng, Economic integration agreements and the margins of international trade. Journal of International Economics 93, 339-350 (2014).

4. E. Cieslik, J. Bieganska, S. Sroda-Murawska, The Intensification of foreign trade in post-socialist countries and their role in global value chain. Acta Oeconomica 66, 465487 (2016).

5. Q. T. Do, A. A. Levchenko, C. Raddatz, Comparative advantage, international trade, and fertility. Journal of Development Economics 119, 148-166 (2016).

6. A. Fracasso, G. V. Marzetti, International trade and R\&D spill overs. Journal of International Economics 96, 138-149 (2015).

7. C. Giordano, F. Zollino, Shedding light on price- and non-price-competitiveness determinants of foreign trade in the four largest Euro-area countries. Review of International Economics 24, 604-634 (2016).

8. I. S. Gladkov, European union in modern international trade. Contemporary EuropeSovremennaya Evropa 1, 85-94 (2016).

9. L. Paškrtová, Dependence of Slovak economy growth on foreign trade. Proceedings of $16^{\text {th }}$ International Scientific Conference Globalization and Its Socio-Economic Consequences, Rajecké Teplice, Slovakia, pp. 1642-1648, 2016.

10. G. Vannoorenberghe, International trade, risk taking and welfare. Journal of International Economics 92, 363-374 (2014).

11. J. Kovárník, E. Hamplová, The Analysis of foreign trade development in the countries of Visegrad four. Proceedings of $19^{\text {th }}$ International Colloquium on Regional Sciences, Brno, Czech Republic, pp. 240-246, 2016.

12. J. Kovárník, E. Hamplová, Selected topics of foreign trade in the Czech Republic and in Slovakia. Proceedings of $17^{\text {th }}$ International Scientific Conference Globalization and Its Socio-Economic Consequences, Rajecké Teplice, Slovakia, pp. 1112-1120, 2017.

13. A. Sacio-Szymanska, A. Kononiuk, S. Tommei, O. Valenta, E. Hideg, J. Gaspar, P. Markovič, K. Gubova, B. Boorova, B., The future of business in Visegrad four. European Journal of Futures Research 4, 25-37 (2016).

14. Eurostat A, (August 2019). International trade of EU, the Euro area and the member states. [Online]. Available: http://ec.europa.eu/eurostat/web/internationaltrade/data/database.

15. Eurostat B, (August 2019). GDP and main components. [Online]. Available: http://ec.europa.eu/eurostat/web/national-accounts/data/database. 